\title{
LEVELS AND CONGENER PROFILES OF DIOXINS, FURANS AND DIOXIN-LIKE PCBS IN CERTAIN EGYPTIAN COW'S MILK FARMS
}

El-Nawawy, M. ${ }^{(1)}$; Amer, M. E. ${ }^{(2)}$ and Abdel Mootaal, M. R. ${ }^{(2)}$

1) Institute of Environmental Studies and Research, Ain Shams University

2) Agriculture Research Center

\begin{abstract}
Levels of polychlorinated dibenzo-p-dioxins, dibenzofurans (PCDD/Fs) and dioxin like-PCBs (dl-PCBs) were determined in thirty five pooled raw cow milk and fifty nine animal feedstuffs samples including silage, hay, cereals and other farinaceous feed, premixes and mixed feeds were consequently collected from different regions of Egypt farms [Qaliubiya, Banha, Sharkia, Monoufia, Damietta, Kafr El-Sheikh, Gharbiya, Ismailia, Port Said, Noubaria (Beheira), Fayoum and Beni Suef]. The method performance used was assessed through successfully participation in specific interlaboratory studies (food and feed) organized by European Union Reference Laboratory for Dioxins and PCBs in Food and Feed. The obtained results showed that $\mathrm{PCDD} / \mathrm{Fs}$ concentrations in cow milk ranged between

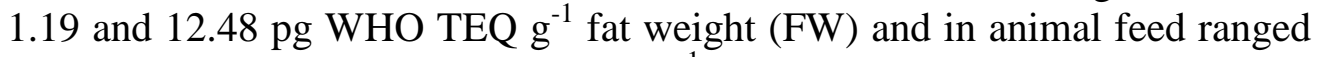
between 0.08 and 1.43 pg WHO TEQ $\mathrm{g}^{-1}$ dry matter (DM), however dl-PCBs concentrations in cow milk ranged between 0.14 and 3.7 pg WHO TEQ g ${ }^{-1}$ (FW) and animal feed ranged between 0.01 and $0.38 \mathrm{pg}^{\text {WHO-TEQ }} \mathrm{g}^{-1}$ (DM). The mean concentration of PCDDs/PCDFs was $0.32 \mathrm{pg}^{\mathrm{TEQ} \mathrm{g}^{-1}}$ dry matter (DM) for animal feed, this level proved to be below the maximum (EU) limits

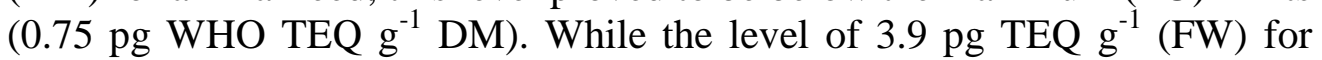
cow milk proved to be higher than the acceptable European (EU) standards limits for milk (3 pg WHO TEQ $\mathrm{g}^{-1} \mathrm{FW}$ ). However the mean concentration of dl-PCBs was $0.05 \mathrm{pg}$ TEQ $\mathrm{g}^{-1}(\mathrm{DM})$ for animal feed which was below the maximum (EU) limits for feed $\left(0.5 \mathrm{pg}\right.$ WHO TEQ $\left.\mathrm{g}^{-1} \mathrm{DM}\right)$. The obtained dlPCBs level of $0.98 \mathrm{pg}^{\mathrm{TEQ} \mathrm{g}^{-1}}$ (FW) for cow milk was below the acceptable EU standards limits for milk ( 3 pg WHO TEQ $\mathrm{g}^{-1} \mathrm{FW}$ ). These finding showed that animal feed have often been reported as the major source to the PCDD/Fs
\end{abstract}


and dl-PCBs intake into the cow milk chain, which characterized in parallel by the total TEQ (dioxin and dl-PCBs). Data revealed that the sum of furan (TEQ) was the predominant group with contribution by 49.96 and $42.51 \%$; followed by the sum of dioxin (TEQ) with contribution by 29.66 and $44.46 \%$; followed by the sum of non-ortho PCBs (TEQ) with contribution by 18.1 and $11.48 \%$ and then the sum of mono-ortho PCBs (TEQ) with contribution by 2.27 and $1.54 \%$ in cow milk and animal feed, respectively. Finally, the present results indicated that the general exposure of the population in Egypt to the main highest persistent organic pollutants was carried through cow milk and animal feedstuffs intake.

Key words: Dioxins, dioxin like-PCBs, Egypt, raw cow milk, animal feedstuffs and World Health Organization (WHO).

\section{INTRODUCTION}

Dioxins, which include polychlorinated dibenzo-p-dioxins (PCDDs), polychlorinated dibenzofurans (PCDFs), and dioxin-like polychlorinated biphenyls (dioxin-like PCBs) are highly toxic environmental pollutants that are distributed worldwide and are found in foods (Schmid et al., 2002). Dioxins, furans and PCBs mediate their toxic effects via their affinity for the aryl hydrocarbon receptor (Denison et al., 1991), these molecules have been attributed toxic equivalency factors (TEFs) that translate their toxicity in terms of 2,3,7,8-TCDD equivalents, the most toxic congener (Van den Berg et al., 1998). Due to their persistence and lipophilic character, they tend to concentrate in the food chain. Humans are at the top of food chain, so human tissues contain high levels of dioxins (Marin et al., 2011 and Kim et al., 2013). Ingestion of contaminated food is the major route of human exposure to these compounds, accounting for $>90 \%$ of the exposure, with inhalation and dermal contact accounting for the rest (Esposito et al., 2009); particularly 
dairy products, meat, fish and seafood (Marin et al., 2011). Moreover, dairy products represent at least $40 \%$ of daily intake of these compounds (O’Donovan et al., 2011).

Milk is a rich and convenient source of nutrients (CODEX, 2004). As an excretion of the mammary gland, it may carry several xenobiotic substances, which constitute a risk factor to consumers' health (Licata et al., 2004). Milk fat is likely to be among the highest dietary sources of exposure to persistent, bioaccumulative and toxic (PBT) contaminants, thus it is important to understand PBT levels generally in milk and especially in fatty dairy products. Feedstuffs are the main input source of PCDD/Fs and PCBs into food of animal origin. Due to the so called "carry-over effects" these substances turn over from feedstuffs into foods of animal origin and accumulate (Fattore et al., 2006).

In Egypt there is lack of information to the dioxins evaluation in food (Loutfy et al., 2006; 2007) and the estimation of PCDD/Fs and PCBs exposure. The aim of this study was to determine, investigate the contamination levels and congener profiles of dioxins and PCBs in cow milk and animal feedstuffs from different Egyptian dairy farms and the relationship between them by using high resolution gas chromatography/high resolution mass spectrometry (HRGC/HRMS).

\section{MATERIALS AND METHODS}

Experiments were carried out according to USEPA-1613B (1994) and 1668B (2008) methods. 
Samples collection and processing: A total number of thirty five pooled raw cow milk and fifty nine animal feedstuffs samples including silage, hay, cereals and other farinaceous feed, premixes and mixed feeds were consequently collected from different Egyptian farms [Qaliubiya, Banha, Sharkia, Monoufia, Damietta, Kafr El-Sheikh, Gharbiya, Ismailia, Port Said, Noubaria (Beheira), Fayoum and Beni Suef] during 2011-2013. The farms were sited in rural areas, near urban and industrial zones, to determine the levels of PCDDs/PCDFs and dl-PCBs. The collected samples were transfered frozen to the laboratory in refrigerator car lab. Milk samples were pooled collected from the dairy production of individual farms in amber clean glass recipients. All samples were stored upon receipt at the laboratory and maintained at $-20^{\circ} \mathrm{C}$ until preparation to analysis, while animal feed samples which containing a high water amount were left to dry at room temperature in the fume hood lab before the analysis. Their moisture content was determined in drying oven at $103^{\circ} \mathrm{C}$ allowing the calculation of $\mathrm{PCDD} / \mathrm{Fs}$ and dl-PCBs concentrations considering $12 \%$ moisture content, as requested by the EU legislation (EC, 2006a), then kept at $-20^{\circ} \mathrm{C}$ until preparation to analysis.

Chemicals and Reagents: All chemicals and reagents used were analytical grade for dioxins analysis.

Standard solutions: Labeled-compound (Spiking solution): This solution was purchased as readymade (EPA 1613 and EPA1668 LCS) for dioxins and dl-PCBs, respectively from Wellington Laboratories Inc. 
Internal Standard: It was purchased as readymade solution (EPA 1613 and EPA1668 ISS) for dioxins and dl-PCBs, respectively from Wellington Laboratories Inc.

\section{Method of analysis:}

\section{Extraction of milk samples}

An aliquot of (100g fresh weight) liquid milk sample was spiked with known amounts of a standard mixture of isotopically labeled analogs of ${ }^{13} \mathrm{C}_{12}$ PCDDs/PCDFs and dl-PCBs. The milk sample was processed firstly by sodium oxalate assisted liquid/liquid extraction (LLE), then secondly ethyl alcohol was added in order to precipitate proteins and then fat was extracted by a mixture of diethyl ether: Hexane 1:2(v/v). Thereafter, the extract was rotary evaporated, and the milk fat content was gravimetrically calculated.

\section{Extraction of animal feed samples}

After grinding feed-stuffs, an aliquot of (10g dry weight) sample was spiked with known amounts of a standard mixture of isotopically labeled analogs of ${ }^{13} \mathrm{C}_{12}$ PCDDs/PCDFs and dl-PCBs, and Soxhlet-extracted (SE) over to $24 \mathrm{~h}$ with a mixture of n-hexane/dichloromethane 50:50 (v/v) in order to evaporate it prior to cleanup.

\section{Clean up of the extract:}

The clean-up and fractionation were carried out on the milk fat and animal feed extracted samples by adsorption chromatography as four successive clean-up steps, with acidified silica gel, multi-layer silica gel, alumina and carbopack/celite mixture columns. 
J. Environ. Sci.

Institute of Environmental Studies and Research - Ain Shams University

\section{DETERMINATION OF PCDD/Fs and DL-PCBs BY HRGC/HRMS:}

The standards and samples were injected in the splitless mode. The injection volumes were 1 and $2 \mu 1$ of each sample for dl-PCBs and PCDD/Fs respectively. Pollutants were identified and quantified using an HRGCHRMS, using an Agilent 6890N (Agilent Technologies, USA) with an DB$5 \mathrm{MS}$ capillary column $(60 \mathrm{~m}$ length, $0.25 \mathrm{~mm}$ ID, $0.25 \mu \mathrm{m}$, Agilent Technologies JW Scientific, USA) coupled to an AutoSpec Ultima NT mass spectrometer (Waters Corporation, USA), using a positive electron ionization (EI+) mode at $35 \mathrm{eV}$ and with a resolution of 10.000 (5\% valley). Oven GC program was set $90^{\circ} \mathrm{C}(1 \mathrm{~min}), 15^{\circ} \mathrm{C} \mathrm{min}^{-1}$ to $220^{\circ} \mathrm{C}(15 \mathrm{~min})$ followed by $8^{\circ} \mathrm{C} \min ^{-1}$ to $290^{\circ} \mathrm{C}(18 \mathrm{~min})$ and $(7 \mathrm{~min})$, for PCDD/Fs and dl-PCBs, respectively. Helium at a constant flow rate of $1 \mathrm{ml} \mathrm{min}^{-1}$ was used as carrier gas. Quantification of selected compounds was done following the isotope dilution method for each target compound using QuanLynx software (Waters Corporation, USA). Results were expressed both in pg.g $\mathrm{g}^{-1}$ dry and fat weight for animal feed and cow milk, respectively and in WHO-TEQ using TEF values described by Van den Berg et al., (1998).

TEQ values were calculated as upper bounds assuming the limit of determination (LOD) $\mathrm{S} / \mathrm{N}=3$ for those below the LOD were equal to their limit of determination as recommended by the European Commission Regulation (Council Regulation EC No. 2375/2001) in which mean that the values were below their LOD, would taken their LOD. Detection and quantification limits, as well as recoveries, for all $\mathrm{PCDD} / \mathrm{F}$ and dl-PCBs congeners were in good agreement with the requirements established in the 
Commission Directive 2002/69/CE and 2004/44/EC laying down the methods of sampling and analysis for the official control of PCDD/Fs and dl-PCBs in food and feedstuffs. The mean PCDD/Fs labeled recoveries (\%) of 94.2 ranged between (80.1 - 126.75) with standard deviation (SD) 1.31 and relative standard deviation $(\mathrm{RSD}) \pm 1.39 \%$, while the mean dl-PCBs labeled recoveries $(\%)$ of 97.01 ranged between $(80-148.54)$ with (SD) 2.24 and $(\mathrm{RSD}) \pm 2.31 \%$.

\section{RESULTS AND DISCUSSION}

The current sum concentrations of $17 \mathrm{PCDD} / \mathrm{F}$ and $12 \mathrm{dl}-\mathrm{PCB}$ congeners in collected cow milk and animal feed samples and their milk fat ratio in various locations from Egypt farms are shown in table (1).

Data in table (1) indicate that the PCDD/Fs and dl-PCBs as TEQ values based on dry matter weight (DW) were calculated for animal feed while on fat basis weight (FW) were calculated for milk samples due to compare the contamination levels with the EU Maximum Levels (EC, 2006a,b). The mean of fat content per $100 \mathrm{~g}$ cow milk fresh weight was $3.54 \%( \pm 0.59)$ ranged between 2.28 and $5.05 \%$.

The highest concentration of PCDD/Fs and dl-PCBs as a total-TEQ was founded in Kafr El-Zayat farm; hence the cow milk, animal feed (protected fat used as vegetable oils) and clover (green fodder) samples were 14.60 pgTEQ/g fat weight (FW), 1.81 and 1.48 pgTEQ.g ${ }^{-1}$ dry weight (DW), respectively. Therefore the contamination of feed plants is possible with particles of dust or soil at the surface of the feed plants which might be as a source of carried over to the lactating animal milk samples. Moreover, the 
highest level of total TEQ of animal feed and cow milk samples were taken from the same farm sited in rural areas and nearby industrial zones Kafr ElZayat (Gharbiya governorate) which exceed the EU maximum limits in food of $6 \mathrm{pg}$ WHO-TEQ $\mathrm{g}^{-1}$ fat weight and the animal feed samples were exceed

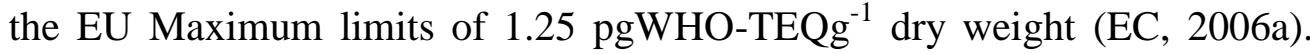
Rychen et al., 2008 estimated from field data the carry-over percentage for a number of dioxins from grass to milk. However, the lowest concentration of PCDD/Fs and dl-PCBs as a total-TEQ was founded in El-Noubaria farm; hence the cow milk was $1.48 \mathrm{pg}^{\mathrm{TEQ}} \mathrm{g}^{-1}$ fat weight and the animal feed

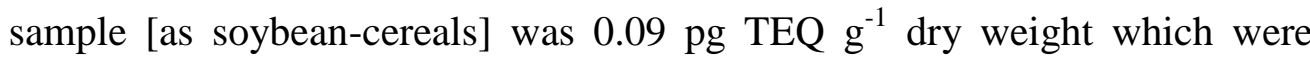
taken from the same farm sited in the modern reclaimed lands near urban areas El-Noubaria (Beheira governorate) in which the lowest concentration of total-TEQ values of milk and feed sample were below the EU standard maximum limits, respectively.

In agreement, the PCDD/Fs and PCBs can carry over from feed plants to the tissues of farmed animals where both undesirable compounds can accumulate in the fat to a greater or lesser extent (Rychen et al., 2008). Due to the high lipophilicity of PCDD/Fs, dl-PCBs and their highly persistence in the environment; they accumulate in the terrestrial food webs, therefore possibly entrance the food chain and can reach concentrations in animal tissues and fat. (Hoogenboom et al., 2010). 
Table (1): Mean, minimum and maximum of fat ratio (\%), $\sum \mathrm{PCDD} / \mathrm{Fs}$, $\sum$ dlPCBs and total TEQ concentrations in cow milk (pg TEQ $\mathrm{g}^{-1}$ fat weight) and animal feed (pg TEQ $\mathrm{g}^{-1}$ dry matter) collected from different locations Egyptian dairy farms.

\begin{tabular}{|c|c|c|c|c|c|c|}
\hline \multirow{2}{*}{ Matrices } & \multirow{2}{*}{$\mathbf{N}$} & \multirow{2}{*}{ Fat $(\%)$} & \multicolumn{4}{|c|}{ Mean (pg TEQ $\mathrm{g}^{-1}$ fat or dry weight) \pm SD } \\
\hline & & & $\sum \mathbf{P C D}$ & /Fs & $\sum \mathrm{dl}-\mathrm{PCBs}$ & Total TEQ \\
\hline \multirow{3}{*}{ Cow Milk } & 35 & $\begin{array}{c}3.54 \pm 0.59 \\
(2.28-5.05)\end{array}$ & $\begin{array}{r}3.9 \pm \\
(1.19-1 \\
\end{array}$ & $\begin{array}{l}58 \\
.48)\end{array}$ & $\begin{array}{l}0.98 \pm 0.77 \\
(0.14-3.7)\end{array}$ & $\begin{array}{c}4.88 \pm 3.18 \\
(1.48-14.6)\end{array}$ \\
\hline & \multirow{2}{*}{.气 } & $\begin{array}{c}\text { Noubaria } \\
\text { (Lowest } \\
\text { Concentration) }\end{array}$ & \multicolumn{2}{|c|}{1.19} & 0.29 & 1.48 \\
\hline & & $\begin{array}{l}\text { Kafr El-Zayat } \\
\text { (Highest } \\
\text { Concentration) }\end{array}$ & \multicolumn{2}{|c|}{12.48} & 2.11 & 14.6 \\
\hline \multirow{4}{*}{ Animal Feed } & 59 & - & $\begin{array}{r}0.32 \pm \\
(0.08 \\
\end{array}$ & \begin{tabular}{|l|}
33 \\
$43)$ \\
\end{tabular} & $\begin{array}{c}0.05 \pm 0.08 \\
(0.01-0.38) \\
\end{array}$ & $\begin{array}{r}0.37 \pm 0.39 \\
\left(0.0^{9}-1.81\right) \\
\end{array}$ \\
\hline & \multirow{3}{*}{ 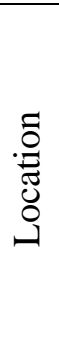 } & $\begin{array}{c}\text { Noubaria } \\
\text { (Lowest } \\
\text { Concentration) } \\
\end{array}$ & Soybean & 0.08 & 0.01 & 0.09 \\
\hline & & \multirow{2}{*}{$\begin{array}{c}\text { Kafr El-Zayat } \\
\text { (Highest } \\
\text { Concentration) }\end{array}$} & Clover & 1.37 & 0.11 & 1.48 \\
\hline & & & $\begin{array}{c}\text { Protect } \\
\text { fat }\end{array}$ & 1.43 & 0.38 & 1.81 \\
\hline
\end{tabular}

N: Number of collected samples, SD: Standard deviation, Values in parentheses indicates the range (minimum - maximum).

In general, the results in table (1) indicate that the mean and concentrations range of PCDD, PCDF and dl-PCB congeners in cow milk and animal feed samples appeared a strong relationship between them, also the results indicated that the animal feed might be one of a potential contamination sources. 
Comparing the milk result of total TEQ (4.88 pgTEQ.g ${ }^{-1}$ fat weight) with the values published for Italian country (3.06 and 5.36 pgTEQ. ${ }^{-1}$ fat weight) (Esposito et al., 2009 and 2010), our obtained data revealed that cow milk of investigated locations from Egypt farms were more contaminated than Italian country according to the previous references.

As for western region samples, the data on cow milk samples collected from Kafr El-Zayat (Gharbiya), a high industrialized rural area, recorded higher values than those detected in samples from Ismailia, Port Said and Noubaria (less industrialized region urban area), especially for the high chlorinated $\mathrm{PCDD} / \mathrm{Fs}$ and $\mathrm{PCBs}$, in which is similar to the levels of organohalogen compounds in the non-industrialized regions of the world are lower for a given environmental compartment than in the high industrialized regions (Storelli, et al., 2012).

Table (2) shows that the maximum contribution level of dioxin to furans by (TEQ) in cow milk was $42.28 \%$; which the dioxin was more toxic than the furan congeners. The contribution of dioxin and furan to the summation of (Dioxin + Furan) TEQ were $29.72 \%$ and $70.28 \%$, respectively; these percentages were generally observed when foodstuffs were contaminated with dl-PCBs (Covaci et al., 2002). While the maximum contribution level of non-ortho-PCBs to mono-ortho-PCBs (TEQ) in cow milk was $418.3 \%$; which the non-ortho was more toxic than mono-ortho. The contribution of non-ortho and mono-ortho to the summation of (non-ortho + mono-ortho) TEQ were $80.71 \%$ and $19.29 \%$, respectively. 
The most abundant PCDD/F congeners in cow milk was OCDF which ranged from 0.22 to $84.53 \mathrm{pg} . \mathrm{g}^{-1}$ fat weight, with an average of $9.94 \mathrm{pg} . \mathrm{g}^{-1}$ fat, followed by OCDD which ranged from 0.174 to $30.825 \mathrm{pg} . \mathrm{g}^{-1}$ fat weight, with an average of $4.45 \mathrm{pgg}^{-1}$ fat, followed by $1,2,3,4,6,7,8-\mathrm{HpCDF}$ and $1,2,3,4,7,8,9-\mathrm{HpCDF}$ with mean value of 4.05 and $2.81 \mathrm{pg} \cdot \mathrm{g}^{-1}$ fat; respectively. While in animal feed the OCDD recorded the highest level of PCDD/F congeners, ranged from 0.05 to 274.24 pg.g ${ }^{-1}$ dry weight, with a mean of $9.35 \mathrm{pg} . \mathrm{g}^{-1}$ dry, followed by HpCDD ranged from 0.025 to $7.24 \mathrm{pg} . \mathrm{g}$ ${ }^{1}$ dry weight, with a mean of $0.54 \mathrm{pg} . \mathrm{g}^{-1}$ dry, followed by $1,2,3,4,6,7,8$ $\mathrm{HpCDF}$ and OCDF with mean value of 0.43 and $0.41 \mathrm{pg} . \mathrm{g}^{-1}$ dry; respectively.

Regarding to the dl-PCB congeners profile in cow milk and animal feed, data showed that the concentrations of non-ortho-PCB congeners were the highest values than mono-ortho-PCB congeners. Also the predominant compound in cow milk was PCB 118 that it's level of concentrations varied between 25.18 and 3385.45 pg.g ${ }^{-1}$ fat, with an average of $429.93 \mathrm{pg}^{-g^{-1}}$ fat weight, followed by PCB 156 varied between 4.18 and $747.44 \mathrm{pg}^{-1}{ }^{-1}$ fat, with an average of $85.6 \mathrm{pg} . \mathrm{g}^{-1}$ fat weight, followed by PCB 105 and PCB 167 with mean value of 70.5 and 55.9 pg. $\mathrm{g}^{-1}$ fat; respectively. While in animal feed the PCB 118 proved to be the predominant congener that it's concentration ranged from 4.09 to $122.11 \mathrm{pg} . \mathrm{g}^{-1}$ dry weight, with a mean of $22.77 \mathrm{pg} . \mathrm{g}^{-1}$ dry, followed by PCB 105 ranged from 1.77 to $48.05 \mathrm{pgg}^{-1}$ dry weight, with a mean of $8.87 \mathrm{pg} \cdot \mathrm{g}^{-1}$ dry, followed by PCB 77 and PCB156 with mean value of 4.66 and $2.78 \mathrm{pg} . \mathrm{g}^{-1}$ dry; respectively. 
In cow milk, the total concentrations of PCDDs ranged from 0.2 to 4.39 $\operatorname{pgTEQg}^{-1}$ fat weight with an average of $1.45 \mathrm{pgTEQg}^{-1}$ fat. While the PCDFs concentrations ranged from 0.21 to $10.38 \mathrm{pgTEQg}^{-1}$ fat weight with an average of $2.44 \mathrm{pgTEQg}^{-1}$ fat. In animal feed, the PCDDs total concentration level varied between 0.01 and $1.33 \mathrm{pgTEQg}^{-1}$ dry weight with a mean of $0.162 \mathrm{pgTEQg}^{-1}$ dry basis, also for PCDFs ranged from 0.02 to $1.09 \mathrm{pgTEQg}^{-}$ ${ }^{1}$ dry basis with an average of 0.155 pgTEQg $^{-1}$ dry weight. Regarding to the dl-PCBs in cow milk, the total concentrations for non-ortho PCBs ranged from 0.13 to $3.6 \mathrm{pgTEQg}^{-1}$ fat weight with an average of $0.88 \mathrm{pgTEQg}^{-1}$ fat and for mono-ortho PCBs, it ranged from 0.01 to $0.86 \mathrm{pgTEQg}^{-1}$ fat weight with an average of $0.11 \mathrm{pgTEQg}^{-1}$ fat. While in animal feed for non-ortho PCBs the total level varied between 0.01 and $0.35 \mathrm{pgTEQg}^{-1}$ dry weight with a mean of $0.04 \mathrm{pgTEQg}^{-1}$ dry and for mono-ortho PCBs it ranged from 0.001 to $0.032 \mathrm{pgTEQg}^{-1}$ dry basis with an average of $0.01 \mathrm{pgTEQg}^{-1}$ dry weight. Our study concluded that the animal feed was the primary source of dioxins and dl-PCBs in dairy cows this finding agreed with the statement of Sapkota et al., 2007.

Several investigators concluded that the concentrations of dioxins and dlPCBs which contaminated of cow milk were comparable to the concentration of dioxins and dl-PCBs in animal feed as a "carry-over modeling rate"; these substances turn over from feedstuffs consumed by lactating animals and accumulate in the adipose tissue (Shunthirasingham et al., 2013 and PizarroAranguiz et al., 2015). 
Table (2): Mean, minimum and maximum concentrations of PCDD, PCDF and dl-PCB congeners in cow milk (pg.g $\mathrm{g}^{-1}$ fat weight) and animal feed samples (pg.g ${ }^{-1}$ dry matter) collected from different locations Egyptian dairy farms.

\begin{tabular}{|c|c|c|c|c|c|}
\hline \multirow[b]{2}{*}{ Compounds } & \multicolumn{2}{|c|}{ Sample matrices } & \multirow[b]{2}{*}{ Compounds } & \multicolumn{2}{|c|}{ Sample matrices } \\
\hline & $\begin{array}{c}\text { Cow Millk } \\
\mathrm{n}=35\end{array}$ & $\begin{array}{c}\text { Animal Feed } \\
\mathrm{n}=59\end{array}$ & & $\begin{array}{c}\text { Cow Millk } \\
\mathrm{n}=35\end{array}$ & $\begin{array}{c}\text { Animal Feed } \\
\mathrm{n}=59\end{array}$ \\
\hline \multicolumn{3}{|c|}{ PCDDs } & \multicolumn{3}{|c|}{ Non ortho-PCB } \\
\hline $2,3,7,8-\mathrm{TCDD}$ & $\begin{array}{c}0.44 \\
(0.4-124)\end{array}$ & $\begin{array}{c}0.05 \\
(0 n 03-0.46)\end{array}$ & $\mathrm{PCB} 77$ & $\begin{array}{c}638 \\
045-2508)\end{array}$ & $\begin{array}{c}4.66 \\
1077-30421\end{array}$ \\
\hline $1,2,3,7,8-\mathrm{PeCDD}$ & $\begin{array}{c}0.82 \\
0.1-2.62)\end{array}$ & $\begin{array}{c}0.08 \\
0.005-0.56)\end{array}$ & PCB 81 & $\begin{array}{c}2.18 \\
(0.32-1116)\end{array}$ & $\begin{array}{c}0.35 \\
(0.06-105)\end{array}$ \\
\hline $1,2,3,4,7,8-\mathrm{HxCDD}$ & $\begin{array}{c}0.43 \\
0.04-1.32)\end{array}$ & $\begin{array}{c}0.06 \\
(0.01-0.35)\end{array}$ & PCB 126 & $\begin{array}{c}8.52 \\
(132-3345)\end{array}$ & $\begin{array}{c}0.4 \\
(0.07-33)\end{array}$ \\
\hline $1,2,3,6,7,8-\mathrm{HxCDD}$ & $\begin{array}{c}0.68 \\
(0.13-17)\end{array}$ & $\begin{array}{c}0.08 \\
0.005-0.811\end{array}$ & PCB 169 & $\begin{array}{c}3.11 \\
(0.34-2477)\end{array}$ & $\begin{array}{c}0.17 \\
(0.01-148)\end{array}$ \\
\hline $1,2,3,7,8,9-\mathrm{HxCDD}$ & $\begin{array}{c}0.63 \\
(0 \cap 8-162)\end{array}$ & $\begin{array}{c}0.11 \\
(0,005-084)\end{array}$ & N-0-PCBs (TEQ) & $\begin{array}{c}0.88 \\
(013-36)\end{array}$ & $\begin{array}{c}0.04 \\
(001-035)\end{array}$ \\
\hline $\begin{array}{c}1,2,3,4,6,7,8- \\
\mathrm{HpCDD}\end{array}$ & $\begin{array}{c}1.65 \\
(0.27-6.88)\end{array}$ & $\begin{array}{c}0.54 \\
(0.025-7.24)\end{array}$ & \multicolumn{3}{|c|}{ Mono ortho-PCB } \\
\hline $\begin{array}{c}1,2,3,4,6,7,8,9- \\
\text { OCDD }\end{array}$ & $\begin{array}{c}4.45 \\
(0.17-30.83) \\
\end{array}$ & $\begin{array}{c}9.35 \\
(0.05-27424)\end{array}$ & PCB 105 & $\begin{array}{c}70.52 \\
(6.43-344.68)\end{array}$ & $\begin{array}{c}8.87 \\
(1.77-48.05)\end{array}$ \\
\hline PCDDs (TEQ) & $\begin{array}{c}1.45 \\
(0.20-439)\end{array}$ & $\begin{array}{c}0.162 \\
(0.01-1.33)\end{array}$ & PCB 114 & $\begin{array}{c}12.57 \\
(1.02-84.4)\end{array}$ & $\begin{array}{c}1.12 \\
(0.19-6.86)\end{array}$ \\
\hline \multicolumn{3}{|c|}{ PCDFs } & PCB 118 & $\begin{array}{c}42993 \\
(25.18-338545)\end{array}$ & $\begin{array}{c}22.77 \\
(4.09-122.11\end{array}$ \\
\hline $2,3,7,8-\mathrm{TCDF}$ & $\begin{array}{c}0.83 \\
(0.15-2.31) \\
\end{array}$ & $\begin{array}{c}0.22 \\
(0.04-1.17) \\
\end{array}$ & PCB 123 & $\begin{array}{c}12.19 \\
(1.45-62.42)\end{array}$ & $\begin{array}{c}0.77 \\
(0.13-4.16) \\
\end{array}$ \\
\hline $1,2,3,7,8-\mathrm{PeCDF}$ & $\begin{array}{c}1.24 \\
(0.23-4.28)\end{array}$ & $\begin{array}{c}0.16 \\
(0.02-1.2)\end{array}$ & PCB 156 & $\begin{array}{c}85.6 \\
(4.18-747.44)\end{array}$ & $\begin{array}{c}2.78 \\
(0.51-16.16)\end{array}$ \\
\hline $2,3,4,7,8-\mathrm{PeCDF}$ & $\begin{array}{c}2.76 \\
(0.17-13.39)\end{array}$ & $\begin{array}{c}0.14 \\
(0.02-1.13)\end{array}$ & PCB 157 & $\begin{array}{c}1759 \\
(1.28-102.64)\end{array}$ & $\begin{array}{c}0.76 \\
(0.12-429)\end{array}$ \\
\hline $1,2,3,4,7,8-\mathrm{HxCDF}$ & $\begin{array}{c}335 \\
(0.37-10.88)\end{array}$ & $\begin{array}{c}0.21 \\
(0.02-1.51)\end{array}$ & PCB 167 & $\begin{array}{c}55.87 \\
(3.14-469.86)\end{array}$ & $\begin{array}{c}1.42 \\
(0.22-9.02)\end{array}$ \\
\hline $1,2,3,6,7,8-\mathrm{HxCDF}$ & $\begin{array}{c}2.02 \\
(0.25-6.45)\end{array}$ & $\begin{array}{c}0.13 \\
(0.01-1.03)\end{array}$ & PCB 189 & $\begin{array}{c}11.26 \\
(0.82-83.73)\end{array}$ & $\begin{array}{c}0.54 \\
(0.04-3.61)\end{array}$ \\
\hline $2,3,4,6,7,8-\mathrm{HxCDF}$ & $\begin{array}{c}1.61 \\
(0.31-3.76)\end{array}$ & $\begin{array}{c}0.11 \\
(0.01-0.49)\end{array}$ & $\mathrm{M}-0$-PCBs (TEQ) & $\begin{array}{c}0.11 \\
(0.01-0.86)\end{array}$ & $\begin{array}{c}0.01 \\
(0.001-0.032)\end{array}$ \\
\hline $1,2,3,7,8,9-\mathrm{HxCDF}$ & $\begin{array}{c}1.5 \\
(0.05-7.08)\end{array}$ & $\begin{array}{c}0.08 \\
(0.01-0.26)\end{array}$ & & & \\
\hline $\begin{array}{c}1,2,3,4,6,7,8- \\
\mathrm{HpCDF}\end{array}$ & $\begin{array}{c}4.05 \\
(0.33-20.54)\end{array}$ & $\begin{array}{c}0.43 \\
(0.04-1.51)\end{array}$ & PCDDs/Fs (TEQ) & $\begin{array}{c}39 \\
(1.19-12.48)\end{array}$ & $\begin{array}{c}0.32 \\
(0.08-1.43)\end{array}$ \\
\hline $\begin{array}{c}1,2,3,4,7,8,9- \\
\mathrm{HpCDF}\end{array}$ & $\begin{array}{c}2.81 \\
(0.05-20.58)\end{array}$ & $\begin{array}{c}0.09 \\
(0.01-0.33)\end{array}$ & DL-PCBs (TEQ) & $\begin{array}{c}0.98 \\
(0.14-3.7)\end{array}$ & $\begin{array}{c}0.05 \\
(0.01-0.38)\end{array}$ \\
\hline $\begin{array}{c}1,2,3,4,6,7,8,9- \\
\text { OCDF }\end{array}$ & $\begin{array}{c}994 \\
(0.22-84.53)\end{array}$ & $\begin{array}{c}0.41 \\
(0.02-5.73)\end{array}$ & Total (TEQ) & $\begin{array}{c}4.88 \\
(1.48-14.6)\end{array}$ & $\begin{array}{c}0.37 \\
(0.08-1.81)\end{array}$ \\
\hline PCDFs (TEQ) & $\begin{array}{c}2.44 \\
(0.21-1038)\end{array}$ & $\begin{array}{c}0.155 \\
(0.02-109)\end{array}$ & & & \\
\hline
\end{tabular}

$\mathrm{N}$ : Number of collected samples, SD: Standard deviation, Values in parentheses indicates the range (minimum - maximum). 
Regarding to fig. 1 and 2 in the context of total TEQ (dioxin and dlPCBs), showed that the sum of furan (TEQ) was the predominant group with contribution of 49.96 and $42.51 \%$; followed by the sum of dioxin (TEQ) with contribution of 29.66 and $44.46 \%$; followed by the sum of non-ortho PCBs (TEQ) with contribution of 18.1 and $11.48 \%$ and then the sum of mono-ortho PCBs (TEQ) with contribution of 2.27 and $1.54 \%$ in cow milk and animal feed, respectively.

The variability between the different milk samples in terms of their PCDDs/Fs and dl-PCBs contents could be attributed to ambient nature of feed chain, type of feed (green fodder, cereals and feed additives), age of animal, feeding technique, sex, diet of animal and biological cycle. The concentration of these compounds in cow milk was depended on their concentration in pasture or other feed consumed by lactating animals. (Fattore et al., 2006 and Shunthirasingham et al., 2013).

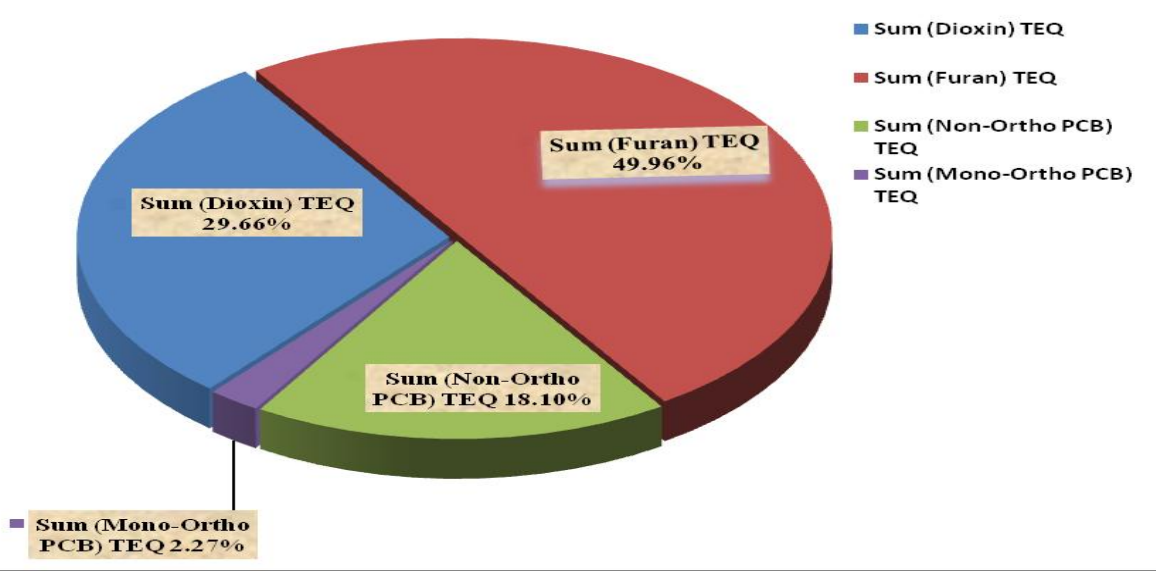

Fig. 1: Contribution percentages as TEQ for dioxin, furan, mono-ortho PCB and non-ortho PCB in cow milk farms 


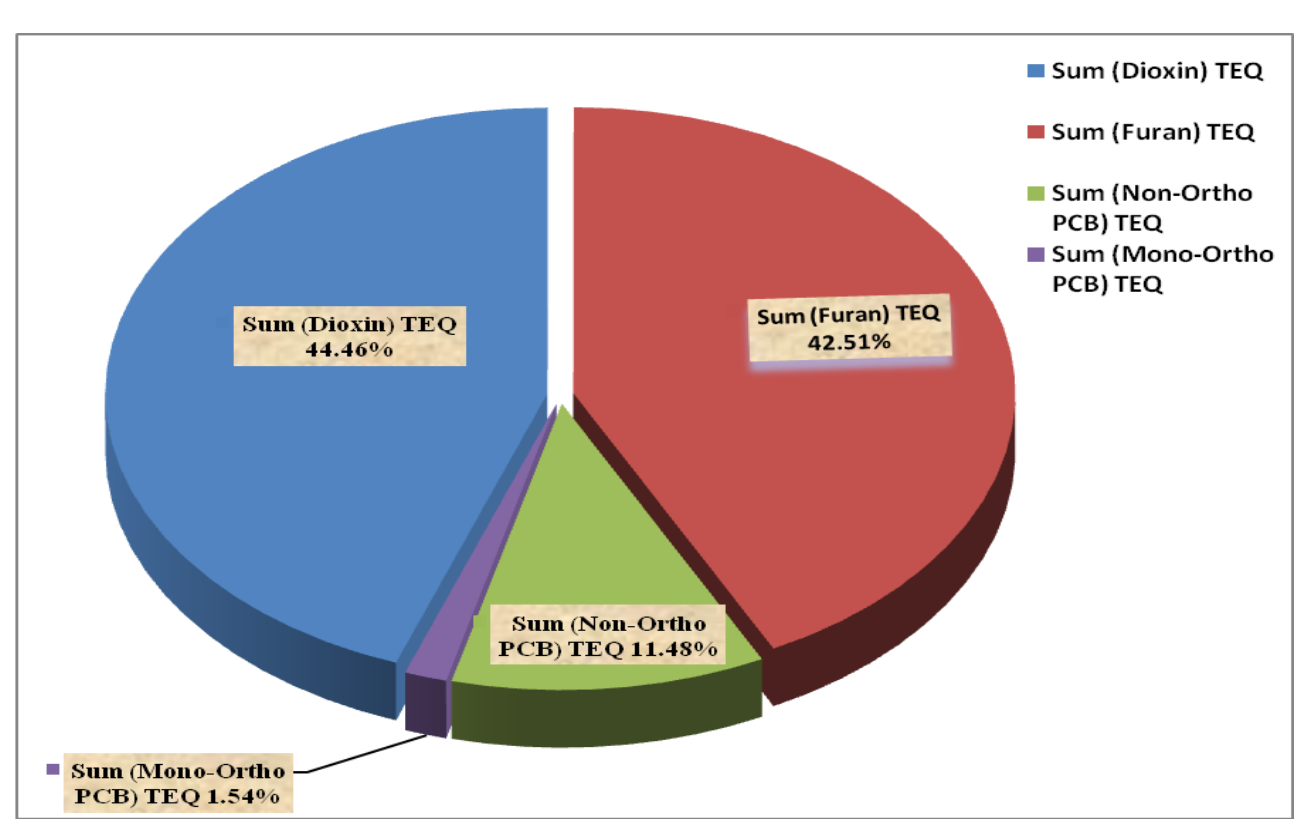

Fig. 2: Contribution percentages as TEQ for dioxin, furan, mono-ortho PCB and non-ortho PCB in animal feed

\section{CONCLUSION}

There are very rare studies on measuring the levels of dioxins and it's related compounds as a pollutant to cow milk in Egypt. In the present study, cow milk and their animal feed samples have been collected and analyzed for measuring the levels of dioxins (from some different Egyptian dairy farms). It shows that the mean of PCDD/Fs TEQ concentration levels in cow milk

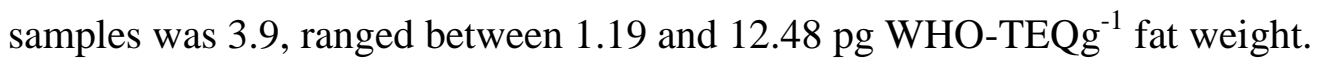
This value exceeded the EU maximum limits [EC, 2006b] (3 pgWHO-TEQg ${ }^{-1}$ fat weight). While the mean of dl-PCBs concentration levels in cow milk

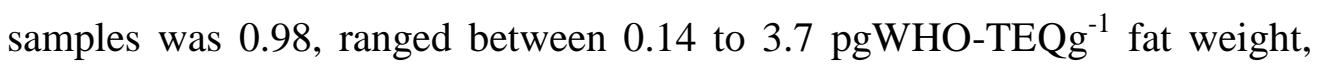
which was far below the EU maximum limits [EC, 2006b] (3 pgWHO-TEQg ${ }^{-}$ 
J. Environ. Sci.

Institute of Environmental Studies and Research - Ain Shams University

${ }^{1}$ fat weight). The mean levels of PCDD/Fs TEQ in animal feed samples was

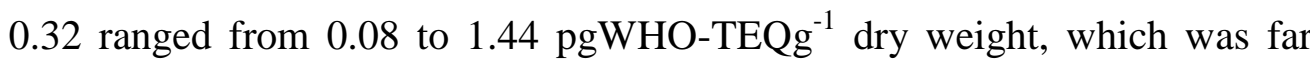
below the EU maximum limits [EC, 2006a] (0.75 pgWHO-TEQg $^{-1}$ dry weight). On the other hand, the mean of dl-PCBs concentration levels in animal feed samples was 0.05 ranged between 0.01 to $0.38 \mathrm{pgWHO}-\mathrm{TEQg}^{-1}$ dry weight which was far below the EU maximum limits [EC, 2006a] (0.75 pgWHO-TEQg ${ }^{-1}$ dry weight). It could be concluded that the concentrations of dioxins and dl-PCBs contaminated cow milk were comparable to it's concentration in animal feed as a "carry-over modeling rate".

The objective of this study was to focus on the levels of dioxins, furans and dioxin like PCBs in cow milk and animal feed samples as a potential contamination sources for the population in Egypt.

\section{REFERENCES}

Codex Alimentarius (CODEX), 2004: Code of hygienic practice for milk and milk products. http://www.codexalimentarius net/download/standards/10087/CXP_057e.pdf.

Commission Directive 2002/69/EC of 26 July 2002: Laying down the sampling methods and the methods of analysis for the official control of dioxins and the determination of dioxin-like PCBs in foodstuffs.

Commission Directive 2004/44/EC of 13 April 2004: Amending Directive 2002/69/EC laying down the sampling methods and the methods of analysis for the official control of dioxins and the determination of dioxin-like PCBs in foodstuffs.

Covaci, A.; Ryan, J.J. and Schepens, P. (2002): Patterns of PCB and PCDD/F in chicken and pork fat following a Belgian food contamination incident. Chemosphere 47, 207-17. 
Denison, M.S.; Phelps, C.L.; DeHoog, J.; Kim, H.J.; Bank, P.A.; Yao, E.F. \& Harper, P.A. (1991): Species variation in Ah receptor transformation and DNA binding. In: Gallo, M.A., Johnson, R.W., Scheuplein, R.J., van der Heijden, K.A. (Eds.), BanburyReport 35 - Biological Basis for Risk Assessment of Dioxins and Related Compounds. Cold Spring Harbor Laboratory Press, New York, USA, pp. 337-347.

Esposito, M.; Cavallo, S.; Serpe, F.P.; D’Ambrosio, R.; Gallo, P.; Colarusso, G.; Pellican,, R.; Baldi, L.; Guarino, A. and Serpe, A. (2009): Levels and congener profiles of polychlorinated dibenzo-pdioxins, polychlorinated dibenzofurans and dioxin like polychlorinated biphenyls in cow's milk collected in Campania, Italy. Chemosphere 77 (9), 1212-1216.

Esposito, M.; Serpe, F.P.; Neugebauer, F.; Cavallo, S.; Gallo, P.; Colarusso, G.; Baldi, L.; Iovane, G. \& Serpe, L. (2010): Contamination levels and congener distribution of PCDDs, PCDFs and dioxinlike PCBs in buffalo's milk from Caserta province (Italy). Chemosphere 79 (3), 341-348.

European Commission (2001): Council Regulation (EC) No. 2375/2001 of 29 November 2001 amending Commission Regulation (EC) No. $466 / 2001$, setting maximum levels for certain contaminants in foodstuffs. Official J. Eur. Commun. L 321, 1-5.

European Commission (2006a): Commission directive 2006/13/EC of 3 February 2006 amending Annexes I and II to Directive 2002/32/EC of the European Parliament and of the Council on undesirable substances in animal feed as regards dioxins and dioxin-like PCBs. Official J. Eur. Union L 32, 44-52.

European Commission (2006b): Commission regulation (EC) No1881/ 2006 of 19 December 2006 setting maximum levels for certain contaminants in foodstuffs. Official J. Eur. Union L 364, 5 -24.

Fattore, E.; Fanelli, R.; Aida, T. and di Domenico, A. (2006): Current dietary exposure to polychlorodibenzo-p-dioxins, polychlorodibenzofurans, and dioxin-like polychlorobiphenyls in Italy. Mol. Nutr. Food Res. 50 (10), 915-921. 
Kim, D.G., Kim, M., and Jang, J.H. (2013): Monitoring of environmental contaminants in raw bovine milk and estimates of dietary intakes of children in South Korea. Chemosphere 93 (3), 561-566.

Licata, P.; Trombetta, D.; Cristani, M.; Giofrè, F.; Martino, D.; Cal, M. and Naccari, F. (2004): Levels of "toxic" and "essential" metals in samples of bovine milk from various dairy farms in Calabria, Italy. Environ. Int. 30 (1), 1-6.

Loutfy, N.; Fuerhacker, M.; Tundo, P.; Raccanelli, S.; El Dien, A.G. and Ahmed, M. T. (2006): Dietary intake of dioxins and dioxin-like PCBs, due to the consumption of dairy products, fish/seafood and meat from Ismailia city, Egypt. Science of the Total Environment, 370(1), 1-8.

Loutfy, N.; Fuerhacker, M.; Tundo, P.; Raccanelli, S. and Ahmed, M. T. (2007): Monitoring of polychlorinated dibenzo-p-dioxins and dibenzofurans, dioxin-like PCBs and polycyclic aromatic hydrocarbons in food and feed samples from Ismailia city, Egypt. Chemosphere, 66(10), 1962-1970.

Marin, S.; Villalba, P.; Diaz-Ferrero, J.; Font, G. and Yusà, V. (2011): Congener Profile, occurrence and estimated dietary intake of dioxins and dioxin-like PCBs in foods marketed in the region of Valencia (Spain). Chemosphere 82 (9), 1253-1261.

O’Donovan, J.V.; O’Farrell, K.J.; O’Mahony, P.; and Buckley, J.F. (2011): Temporal trends in dioxin, furan and polychlorinated biphenyl concentrations in bovine milk from farms adjacent to industrial and chemical installations over a 15 Year period. Veterin. J. 190 (2), e117-e121.

Pizarro-Aránguiz, N.; Galbán-Malagón, C.J.; Ruiz-Rudolph, P.; ArayaJordan, C.; Maddaleno, A. and San Martin, B. (2015): Occurrence, variability and human exposure to Polychlorinated Dibenzo-p-dioxins (PCDDs), Polychlorinated Dibenzofurans (PCDFs) and Dioxin-Like Polychlorinated Biphenyls (DL-PCBs) in dairy products from Chile during the 2011-2013 survey. Chemosphere, 126: 78-87. 
Rychen, G., Jurjanz, S., Toussaint, H. and Feidt, C. (2008): Dairy ruminant exposure to persistent organic pollutants and excretion to milk. Animal 2, 312-323.

Sapkota, A.R.; Lefferts, L.Y.; McKenzie, S. and Walker, P. (2007): What do we feed to food production animals? A review of animal feed ingredients and their potential impacts on human health. Environ. Health Perspect. 115 (5), 663-670.

Shunthirasingham, C.; Wania, F. and MacLeod, M. (2013): Mountain coldtrapping increases transfer of persistent organic pollutants from atmosphere to cows'milk Environ. Sci. Technol. 47 (16), 91759181.

Storelli, M.M.; Scarano, C.; Spanu, C.; De Santis, E.P.L.; Busco, V.P.; Storelli, A.; Marcotrigiano, G.O.; Pizarro-Aránguiz, N.; GalbánMalagón, C.J.; Ruiz-Rudolph, P.; Araya-Jordan, A.; Maddaleno and San Martin, B. (2012): Levels and congener profiles of polychlorinated dibenzo-p-dioxins (PCDDs), polychlorinated dibenzofurans (PCDFs) and polychlorinated biphenyls (PCBs) in sheep milk from an industrialized area of Sardinia, Italy. Food and Chemical Toxicology50:1413-1417.

U.S. EPA (United States Environmental Protection Agency). Method 1613 Revision B (1994): Tetra through octa-chlorinated dioxins and furans by isotope dilution HRGC/HRMS. [vailable at http://nepis.epa.gov/EPA/].

U.S. EPA (United States Environmental Protection Agency). Method 1668 Revision B (2008): Chlorinated biphenyl congeners in water, soil, sediment, and tissue by HRGC/HRMS. [Available at http://nepis.epa.gov/EPA/].

Van den Berg, M.; L.S., Birnbaum; A.T.C., Bosveld; B., Brunstro“” m; P., Cook; M., Feeley; J.P., Giesy; A., Hanberg; R., Hasegawa; S.W., Kennedy; T., Kubiak; J.C., Larsen; F.X.R., Van Leuwen; A.K.D., Liem; C., Nolt; R.E., Peterson; L., Poellinger; S.H., Safe; D., Schrenk; D., Rillitt; M., Tysklind; M., Younes; F., Waern and T., Zachrewski (1998): Toxic equivalency factors (TEFs) for PCBs, PCDDs, PCDFs for humans and wildlife. Environ. Health Perspect.106 (12), 775-792. 


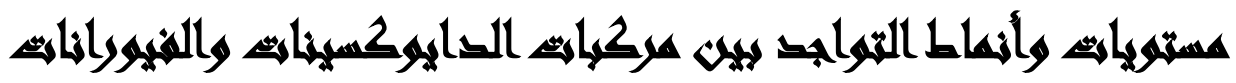

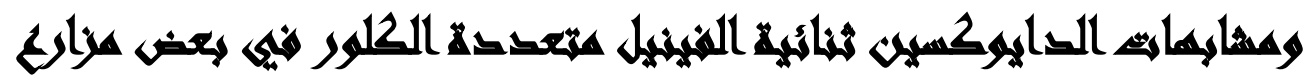 الأرجار اليلارية المصرية}

[9]

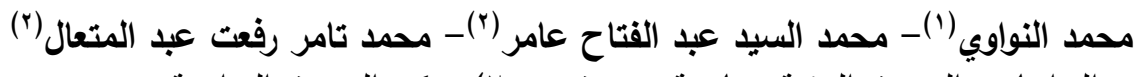

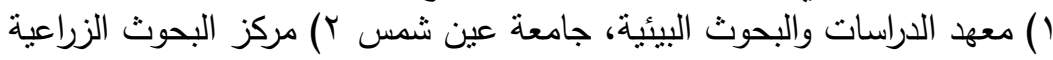

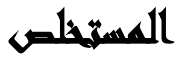

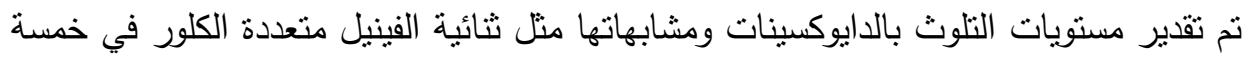

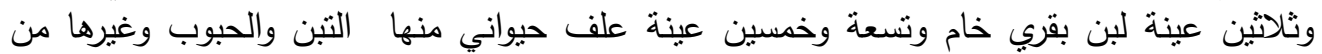

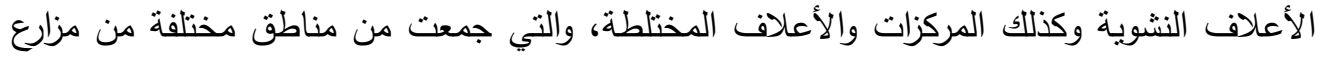

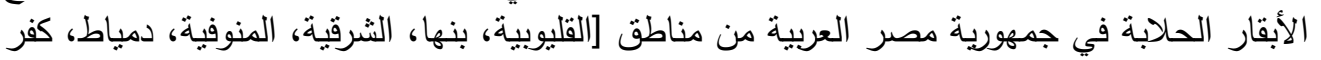

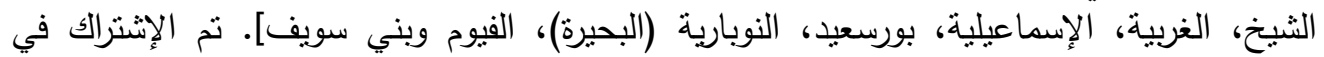

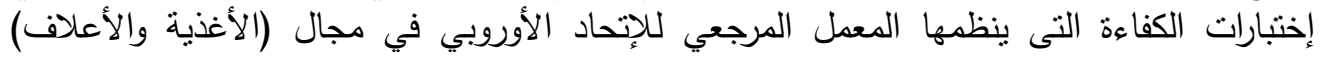

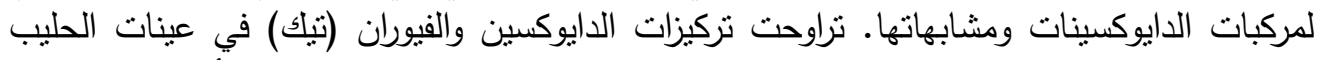

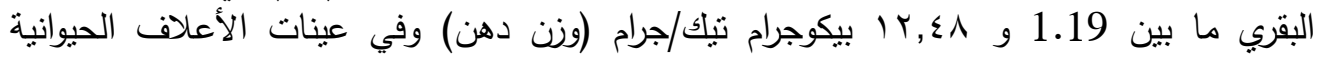

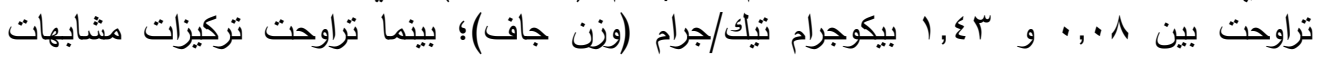

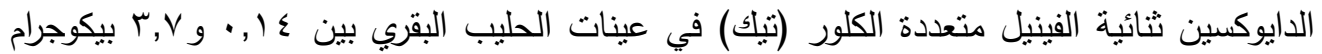

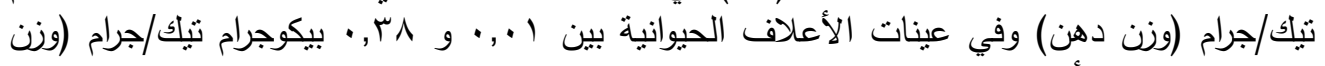

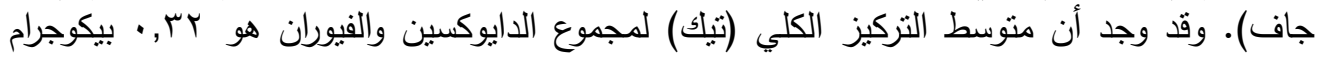

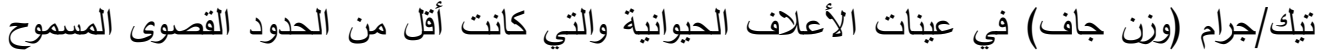

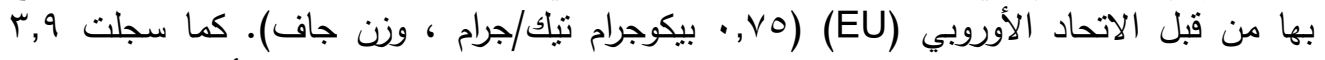

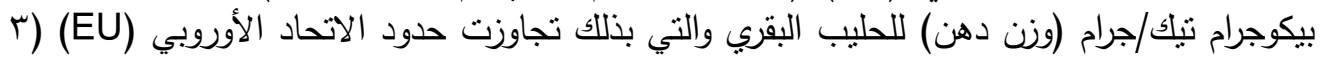

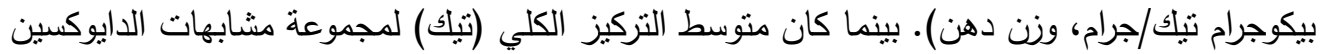

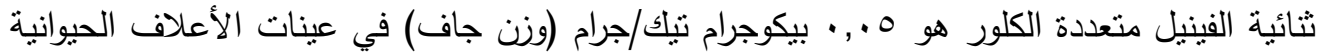

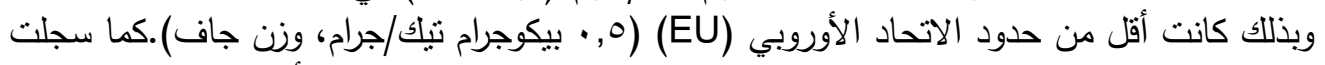

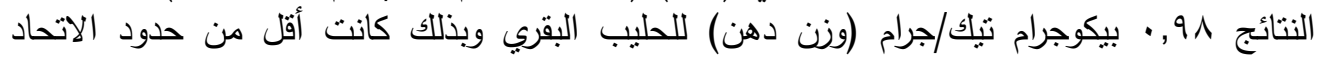

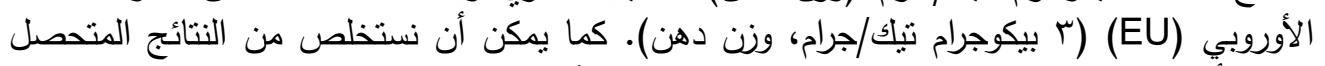

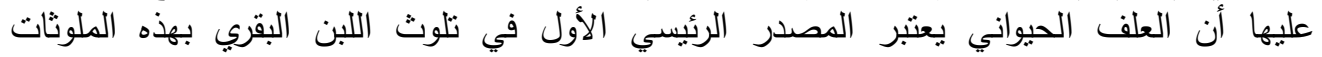

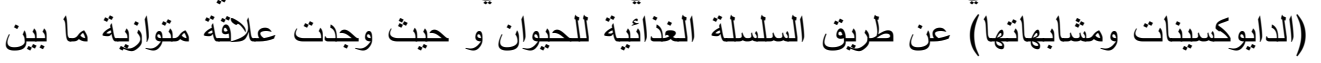


الحليب البقري و الأعلاف الحيوانية من قبل مجموعات متجانسة والتي كانت أكثر شيوعاً في مجموعة

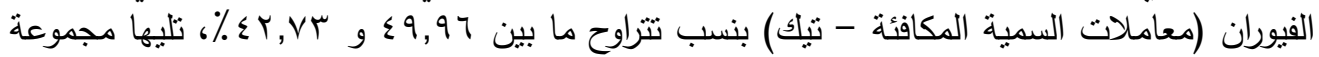

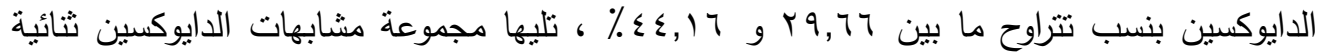

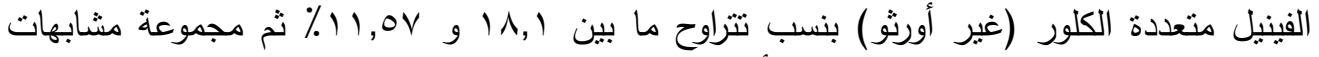

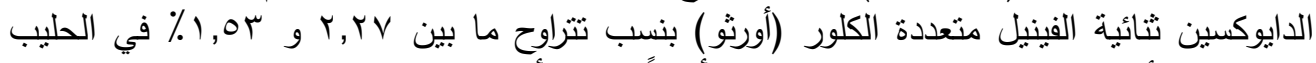

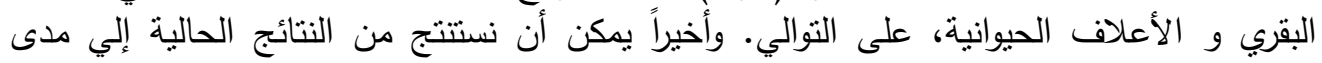

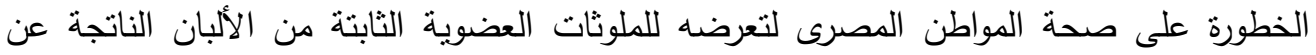
تغذية الأبقار بأعلاف ملوثة بتلك الملوثات. 